\title{
Removal of 2 Sharp Long Pins Embedded in the Gastric Antrum
}

\author{
Mohamed Alshekhani* \\ Faculty of Medical Sciences, University of Sulaimani, Iraq
}

Submission: September 08, 2017; Published: November 14, 2017

"Corresponding author: Mohamed Alshekhani, University of Sulaimani, Faculty of Medical Sciences, School of Medicine, Department of Medicine, Kurdistan Center for Gastroenterology \& Hepatology, Iraq, Email: shaikhanimohammad@gmail.com

\section{Case Report}

Two young patients, the first 18 years old girl \& the second 17 years old male presented to my private endoscopy clinic with history of accidental swallowing of pins \& upper abdominal discomfort. On upper gastrointestinal endscopy, a the pin was seen embedded in the gastric antrum near the pylorus in both cases. With the use of the biopsy forceps the pin was removed in the first cases while in the second case snare was used to remove the pin sucessully. Both patients did well on follow up \& no signs of perforation was detected (Figures). Two young patients, the first 18 years old girl \& the second 17 years old male presented to my private endoscopy clinic with history of accidental swallowing of pins \& upper abdominal discomfort. On upper gastrointestinal endscopy, a the pin was seen embedded in the gastric antrum near the pylorus in both cases. With the use of the biopsy forceps the pin was removed in the first cases while in the second case snare was used to remove the pin sucessully. Both patients did well on follow up \& no signs of perforation was detected (Figures).
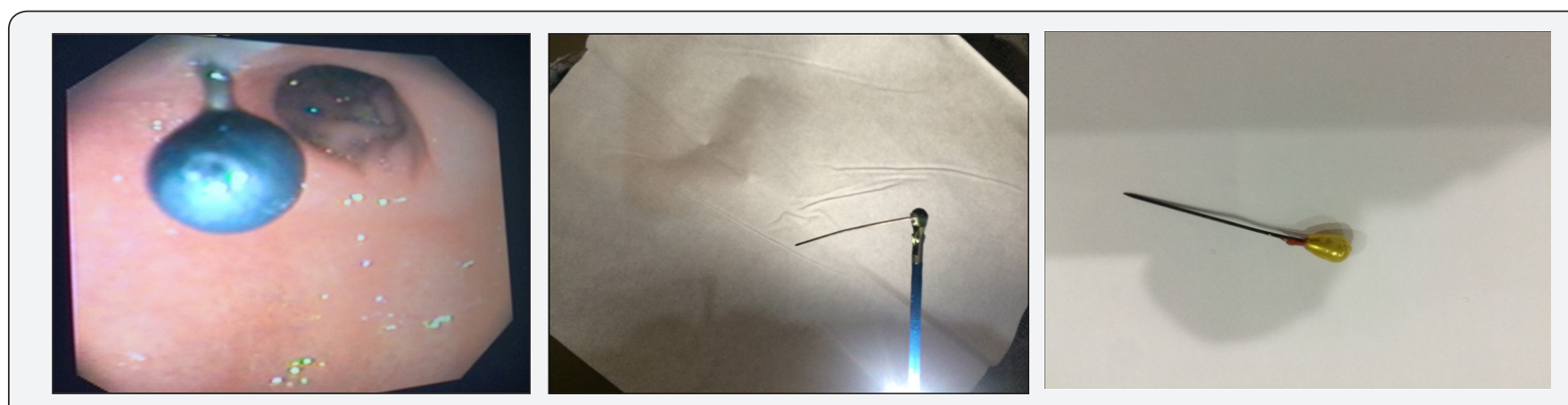

Figures: The consent of the 2 patients taken.

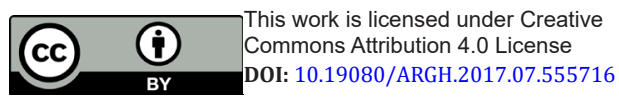

Your next submission with JuniperPublishers will reach you the below assets

- Quality Editorial service

- Swift Peer Review

- Reprints availability

- E-prints Service

- Manuscript Podcast for convenient understanding

- Global attainment for your research

- Manuscript accessibility in different formats ( Pdf, E-pub, Full Text, audio)

- Unceasing customer service

Track the below URL for one-step submission https://juniperpublishers.com/online-submission.php 